\title{
ANALISA FAKTOR KUALITAS PELAYANAN, HARGA, FASILITAS DAN KEPERCAYAAN TERHADAP LOYALITAS KONSUMEN
}

\author{
Hasan Ubaidillah \\ Fakultas Bisnis, Hukum dan Ilmu Sosial, Universitas Muhammadiyah Sidoarjo \\ Email: ubaid@umsida.ac.id
}

\begin{abstract}
Abstrak
Penelitian ini bertujuan untuk menganalisis pengaruh pelayanan, harga, fasilitas, dan kepercayaan terhadap loyalitas konsumen. Penelitian ini dilakukan dengan survei di 9 Toko Retail Modern di Kawasan pasar wisata Tanggulangin Sidoarjo. Penelitian ini menggunakan accidental sampling, dengan jumlah sampel sebanyak 77 konsumen. Analisis data yang digunakan dalam penelitian ini adalah regresi regresi linier berganda. Dari hasil penelitian ini mengungkapkan bahwa Pelayanan,Harga,Fasilitas dan Kepercayaan berpengaruh positif terhadap Loyalitas dan variabel Pelayanan memiliki detirminasi paling dominan dibanding tiga yang lain.
\end{abstract}

Kata kunci : Pelayanan, Harga, Fasilitas, Kepercayaan dan Loyalitas

\begin{abstract}
This study aims to analyze the effect of service, price, facilities, and trust in consumer loyalty. This research was conducted by surveying 9 Modern Retail Stores in the Tanggulangin Sidoarjo tourist market area. This study uses accidental sampling, with a total sample of 77 consumers. Analysis of the data used in this study is multiple linear regression regression. From the results of this study revealed that Service, Price, Facilities and Trust have a positive effect on Loyalty and Service variable has the most dominant detirmination compared to the other three.
\end{abstract}

Keywords: Service, Price, Facilities, Trust and Loyalty

\section{PENDAHULUAN}

Pada era yang semua sudah digital ini konsumen dengan mudah memperoleh informasi sebagai bahan pertimbangan untuk menentukan pilihannya. Pengaruh globalisasi dan kemajuan teknologi saat ini, situasi pasar saat ini berbeda jauh sekali di bandingkan situasi pasar sebelumnya. Kondisi ini mengharuskan setiap perusahaan menemukan strategi yang tepat untuk menghasilkan nilai tambah yang dapat di pasarkan (market value), baik berupa produk barang dan jasa yang menarik minat beli konsumen serta memenangkan persaingan pasar. Persaingan adalah keadaan ketika organisasi berperang atau berlomba untuk mencapai hasil atau tujuan yang diinginkan seperti konsumen, pangsa pasar, peringkat survei, atau sumber daya yang dibutuhkan (Mudrajad, 2006:86). Oleh karena itu perusahaan harus memiliki sistem manajemen dan strategi pemasaran yang mampu menciptakan, mempertahankan, dan meningkatkan kepuasan pelanggan.

Pada umumnya kepuasan pelanggan adalah harapan dari pelanggan yang merupakan kepercayaan atau ekspektasi pelanggan tersebut tentang apa yang akan diterimanya yang diungkapkan baik lisan maupun non lisan. Harapan pelanggan tersebut dibentuk oleh pengetahuan dan juga 
pengalaman dari pembelian sebelumnya, dan harapan pelanggan tersebut dari waktu ke waktu berkembang seiring dengan semakin bertambahnya pengalaman dan pengetahuan pelanggan. Pada dasarnya harapan pelanggan yang paling utama adalah kepuasan, pelanggan lebih memikirkan apa yang akan dibelinya dapat memuaskannya sesuai dengan kebutuhan pelanggan tersebut.

Semua perusahaan baik barang maupun jasa, sudah barang tentu harus menyadari tentang kepuasan pelanggan, untuk mendapatkan pelanggan yang loyal, Grifin dalam Sofiati,lis dkk (2018) menyatakan bahwa apabila penilaian pelanggan merasa baik terhadap kualitas pelayanan, maka pelanggan akan melakukan pemakaian ulang, bahkan pelanggan dengan suka rela mempromosikan kepada orang lain dan akan menolak terhadap tawaran pesaing. Artinya kepuasan pelanggan tidak hanya membeli produk tetapi juga membeli pelayanan.

Semua pelanggan berharap akan mendapat kepuasan baik dari produk yang dia beli, harganya, fasilitas, kualitas pelayanannya dan juga pelayanan sebelum dan sesudah membeli produk tersebut, dan pelanggan berhak akan informasi yang benar dan kesesuaian produk dengan promosinya, lalu kesesuaian produk dengan harga dan kesesuaian produk dengan pelayanan. Permasalahan kepuasan pelanggan akan muncul jika salah satu faktor saja tidak terpenuhi, misalkan pelayanan yang buruk, harga yang tidak sesuai, atau fasilitas yang tidak memadai sehingga dapat menurunkan kepercayaan yang pada akhirnya berpengaruh pada loyalitas pelanggan.

Berdasarkan permasalahan sebagaimana diuraikan dalam latar belakang di atas, maka masalah-masalah dalam penelitian ini dapat diidentifikasi sebagai berikut; Apakah variabel Kualitas pelayanan (x1), Harga(x2),Fasilitas(x3) dan Kepercayaan(x4) dapat mempengaruhi variabel Loyalitas Pelanggan $(\mathrm{Y})$ baik secara parsial maupun simultan?; dan Dari variabel kualitas pelayanan, harga, fasilitas, dan kepercayaan manakah yang paling berpengaruh signifikan terhadap loyalitas konsumen?.

\section{METODE PENELITIAN}

Penelitian membuktikan hubungan kausal antara variabel bebas pelayanan,harga,fasilitas dan kepercayaan dan variabel terikat loyalitas pelanggan. Populasi dalam penelitian ini adalah konsumen yang melakukan pembelian di 9 Toko Retail Modern di Kawasan pasar wisata Tanggulangin Sidoarjo. Penelitian ini menggunakan accidental sampling, jumlah sampel ditentukan berdasarkan kriteria bahwa pengambilan sampel sebanyak 5 sampai 10 kali jumlah indikator. Pada penelitian ini jumlah indikator adalah sebanyak 20 sehingga jumlah sampel pada penelitian ini ditentukan sebanyak 77 konsumen.

Teknik analisis data yang digunakan dalam penelitian ini adalah analisis regresi linier berganda (multiple regression analysis), yang merupakan uji statistik dengan studi ketergantungan satu variabel yang disebut variabel tidak bebas dengan dua atau lebih variabel lainnya yang disebut dengan variabel bebas.

\section{HASIL DAN PEMBAHASAN}

\subsection{Uji Instrumen}

Pada hasil pengujian validitas menyatakan bahwa seluruh item pernyataan kuesioner dari variabel $(\mathrm{X})$ dan variabel $(\mathrm{Y})$ memiliki nilai korelasi diatas $r_{\text {kritis }}$ yang bernilai 0.30 $(>0,30)$, sehingga item pernyataan kuesioner dari variabel $(\mathrm{X})$ dan variabel $(\mathrm{Y})$ dinyatakan valid dan dapat digunakan untuk mengukur variabel yang telah diteliti. Uji reliabilitas dari instrumen penelitian ini mempertimbangkan besarnya koefesien 
reliabilitas. Sesuai dengan hasil analisa data primer maka instrumen yang digunakan dalam penelitian ini memiliki hasil uji yang menunjukkan angka cronbach alpha diatas 0,6, sehingga dari uji reliabilitas dapat dikatakan bahwa seluruh variabel yang digunakan dalam penelitian ini adalah reliabel.

\subsection{Perhitungan Koefisien Regresi}

Tahap selanjutnya adalah perhitungan koefisien path (jalur). Untuk perhitungan parameter dilakukan dengan analisis regresi melalui software SPSS 20 for windows. Hasil dari analisis substruktur persamaan disajikan pada Tabel 1.

\section{Tabel 1.Output Regresi Linier Berganda}

\begin{tabular}{|c|c|c|c|c|}
\hline \multirow{3}{*}{$\begin{array}{l}\text { Variabel } \\
\text { independen } \\
\text { Sig } t\end{array}$} & \multicolumn{4}{|c|}{ UnstandardizedStandardized } \\
\hline & \multicolumn{2}{|c|}{ Coefficients } & \multirow{2}{*}{$\begin{array}{c}\text { Coefficients } \\
\text { Beta }\end{array}$} & \multirow[b]{2}{*}{ Sig. } \\
\hline & B & Error & & \\
\hline (Constant) & 1,764 & ,878 & & $2,009,048$ \\
\hline $\begin{array}{l}\text { Kualitas } \\
\text { Pelayanan } \\
\text { (X1) }\end{array}$ & ,278 & ,087 & ,383 & $3,213,002$ \\
\hline $\begin{array}{l}\text { Harga } \\
\text { (X2) }\end{array}$ &, 234 &, 110 & , 199 & $2,125,037$ \\
\hline $\begin{array}{l}\text { Fasilitas } \\
\text { (X3) }\end{array}$ & ,303 & ,124 &, 255 & $2,440,017$ \\
\hline $\begin{array}{l}\text { Kepercayaan } \\
\text { (X4) }\end{array}$ & ,204 & ,094 & , 126 & $2,101,074$ \\
\hline
\end{tabular}

Dependent Variable: Loyalitas Konsumen Sumber : Data diolah, 2020

Pada Tabel 1 diatas merupakan hasil perhitungan regresi linier berganda untuk mengetahui pengaruh/tidak, besarnya pengaruh antara variabel (Layanan (X1), Harga (X2), Fasilitas, (X3), Kepercayaan (X4) terhadap Loyalitas konsumen (Y). Konstanta $(\alpha)$ nilainya adalah 1,764 menunjukkan bahwa jika variabel bebas yang terdiri dari kualitas pelayanan, harga, fasilitas, dan kepercayaan sebesar 0, maka loyalitas konsumen akan sebesar 1,764. Dari tabel 1 dapat di jelaskan bahwa Koefisien regresi Kualitas Pelayanan sebesar 0,278, harga sebesar 0,234, fasilitas sebesar 0,303 dan kepercayaan sebesar 0,104. Semua variabel menunjukkan hasil koefisien regresi positif dan menunjukkan bahwa adanya

\begin{tabular}{ccccc}
\hline \multicolumn{4}{c}{$\mathbf{R}$} & \multicolumn{2}{c}{ Adjusted } & \\
& Square $\left(R^{2}\right)$ & R & F -hitung & Sig. F \\
& Square & & \\
\hline, 899 &, 808 &, 798 & 75,933 &, 000
\end{tabular}

hubungan yang searah dengan loyalitas konsumen.

Tabel 2: Output Koefesien Determinas

Sumber : Data diolah, 2020

3.3 Hasil Uji $R^{2}$

Uji ini digunakan untuk menghitung kemampuan model regresi dalam menjelaskan perubahan variabel tergantung akibat variabel bebas.

Hasil pengujian Tabel 2 diketahui Adjusted $R$ square $\left(\mathrm{R}^{2}\right)$ sebesar 0,798, hasil menunjukkan bahwa naik turunnya variabel terikat yaitu Loyalitas Konsumen (Y) dipengaruhi oleh variabel bebas yaitu kualitas pelayanan $\left(\mathrm{X}_{1}\right)$, Harga $\left(\mathrm{X}_{2}\right)$, Fasilitas $\left(\mathrm{X}_{3}\right)$ dan Kepercayaan $\left(\mathrm{X}_{4}\right)$ sebesar 7,98\%. Sisanya ditentukan oleh faktor lain yang tidak dijelaskan dalam regresi ini.

\subsection{Hasil Uji Hipotesis}

\subsubsection{Uji Hipotesis secara parsial}

Berdasarkan hasil analisis menunjukkan bahwa variabel kualitas pelayanan mempunyai pengaruh secara persial terhadap loyalitas konsumen. Hal ini dapat ditunjukkan dengan nilai signifikan sebesar $0,002<0,05$ dengan nilai thitung > ttabel $(3,213>1,666)$ serta nilai koefisien regresi sebesar 0,278 sehingga dapat disimpulkan bahwa kualitas pelayanan berpengaruh secara positif dan signifikan terhadap loyalitas konsumen. Hal ini menjelaskan bahwa semakin baik kualitas pelayanan yang diberikan maka loyalitas konsumen akan 
meningkat. kualitas pelayanan yang baik akan sangat menentukan keputusan loyalitas konsumen, karena upaya yang dilakukan perusahaan dalam menghasilkan kualitas terbaik dan sesuai dengan harapan konsumen merupakan faktor kunci keberhasilan bagi perusahaan dalam menciptakan nilai dan keloyalitasan konsumen. Hasil ini sesuai dengan hasil penelitian yazid (2018) yang menyatakan bahwa kualitas merupakan kunci dalam memenang dalam persaingan. Ketika perusahan telah mampu menyediakan produk atau jasa yang berkualitas maka perusahaan telah membangun salah satu fondasi untuk menciptakan kepuasan konsumen. Hasil penelitian ini juga didukung penelitian yang dilakukan oleh Lely Kurnia Sari (2017) yang menyatakan kualitas pelayanan berpengaruh positif teradap loyalitas konsumen kereta Api Dhoho. Hal ini menjelasakan bahwa semakin baik kualitas pelayanan yang diberikan maka loyalitas konsumen akan meningkat.

Sedangkan untuk variabel harga, hasil analisis menunjukkan bahwa variabel harga berpengaruh secara persial terhadap loyalitas konsumen. Hasil ini ditunjukkan dengan nilai signifikan sebesar $0,037<0,05$. Dengan nilai t-hitung $>\mathrm{t}$-tabel $\quad(2,125>1,666)$ serta nilai koefisien regresi sebesar 0,234. Sehingga dapat disimpulkan bahwa harga berpengaruh secara positif dan signifikan terhadap loyalitas konsumen. Harga pada Toko ritael Tanggulangin yang diberikan sesuai dengan apa yang diberikan kepada konsumen dan sudah terbukti dengan baik. Menurut Rambat Lupiyoadi (2013) dalam membuat strategi penetuan harga sangat penting karena itu sebagai proses pembangunan citra produk serta persepsi atas layanan atau jasa dari kinerja produk tersebut.

Hasil penelitian ini dibuktikan juga dengan penelitian yang dilakukan Paulus, dkk (2018) harga mempunyai nilai pengaruh signifikan terhadap loyalitas konsumen, yang berarti bahwa tiap kenaikan satu satuan harga akan manaikkan jumlah loyalitas konsumen. Hasil ini disebabkan karena konsumen menggap harga yang ditawarkan oleh pengguna Aplikasi Gojek tidak berbeda dengan pesaing dan sesuai dengan harga yang tertera sehingga memilih untuk memakai aplikasi Gojek .

Pada analisa terkait fasilitas, hasil analisis menunjukkan bahwa variabel fasilitas berpengaruh secara persial terhadap loyalitas konsumen. Hal ini dapat ditunjukkan dengan nilai signifikan sebesar $0,017<0,05$. Dengan nilai thitung > ttabel $(2,440>1,666)$ serta nilai koefisien regresi sebesar 0,303, dari hasil ini dapat disimpulkan bahwa variabel fasilitas berpengaruh secara positif dan signifikan terhadap variabel loyalitas konsumen. Hal ini menjelaskan bahwa semakin baik fasilitas yang diberikan kepada konsumen maka loyalitas konsumen akan meningkat. Hasil penelitian ini didukung dengan penelitian yang dilakukan oleh Afifah, dkk (2017) bahwa variabel fasilitas mempunyai pengaruh signifikan dan mempunyai arah positif terhadap loyalitas konsumen. Dimana variabel fasilitas yang diberikan sesuai dengan apa yang telah di publikasikan oleh Delta Fishing Sidoarjo oleh karena itu akan menjadikan pelanggan tetap dan loyal terhadap perusahaan.

Untuk variabel Kepercayaan, hasil analisis menunjukkan bahwa variabel kepercayaan tidak berpengaruh secara persial terhadap loyalitas konsumen. Hasil ini dapat ditunjukkan dengan nilai signifikan sebesar $0,074<0,05$, dengan t-hitung $<\mathrm{t}$ tabel $(2,101>1,666)$ serta nilai koefisien regresi sebesar 0,204. Sehingga dapat disimpulkan bahwa variabel Kepercayaan berpengaruh dan signifikan terhadap loyalitas konsumen. Hasil ini didukung dengan 
penelitian yang dilakukan oleh Handoko,Kuttut dan Siparmi (2018) yang menyatakan bahwa Kepercayaan berpengaruh terhadap loyalitas konsumen pada PT. Yodya Karya. Hal ini menunjukkan bahwa respon yang baik untuk kepercayaan menurut data responden akan mendorong loyalitas konsumen untuk melakukan pemakaian jasa pada masa yang akan datang.

\subsubsection{Uji Hipotesis secara Simultan}

Berdasarkan hasil analisis pengujian secara simultan menunjukkan Kemudian pengujian secara simultan yang dapat di peroleh melalui uji $\mathrm{F}$, hasil penelitian menunjukkan nilai Fhitung sebesar 75,933, sedangkan hasil F-tabel pada tabel distribusi sebesar 2,05 sehingga dapat disimpulkan bahwa F-hitung > F-tabel $(75,933>2,50)$ dengan nilai signifikan $(0,000<0,05)$. Dari perhitungan tersebut menyatakan bahwa (Ha) diterima. Secara statistik pengujian ini membuktikan bahwa variabel kualitas pelayanan, harga, fasilitas, dan kepercayaan berpengaruh positif dan berpengaruh secara simultan. Hal ini menunjukkan bahwa variabel bebas kualitas pelayanan, harga, fasilitas dan kepercayaan secara simultan mempunyai pengaruh terhadap loyalitas konsumen. Semua variabel bebas yang meliputi variabel kualitas pelayanan, harga, fasilitas dan kepercayaan berjalan dengan baik terhadap variabel terikat loyalitas konsumen.

Oleh karena itu loyalitas konsumen mengalami kenaikan yang signifikan. Hasil penelitian ini ini sejalan dengan penelitian yang dilakukan oleh Siregar, Nurafrina dan Fadillah, Hakim. 2017 (2017), kualitas pelayanan dan harga secara bersama-sama (simultan) bepengaru positif dan signifikan terhadap loyalitas konsumen. Lely kurnia sari (2017) fasilitas dan kepercayaan secara bersama-sama (simultan) bepengaruh positif dan signifikan terhadap loyalitas konsumen.

Dari ke empat variabel bebas yang terdiri dari kualitas pelayanan, harga ,fasilitas dan kepercayaan dapat diketahui bahwa variabel kualitas pelayanan mempunyai nilai terbesar diantara variabel bebas yang lain. Hasil penelitian ini sependapat dengan penelitian yang dilakukan oleh Sofiati, Iis. Dkk. (2018) yang membuktikan bahwa kualitas pelayanan mempunyai pengaruh signifikan dan mempunyai arah positif terhadap loyalitas konsumen.

\section{KESIMPULAN}

Berdasarkan penelitian yang telah dilakukan tentang pengaruh pelayanan, harga,fasilitas dan kepercayaan terhadap loyalitas konsumen, maka kesimpulan dalam penelitian in adalah: Secara parsial; pelayanan, harga,fasilitas kepercayaan berpengaruh positif terhadap loyalitas konsumen. Sedangkan secara simultan semua variabel berpengaruh positif terhadap loyalitas konsumen, dengan variabel pelayanan memiliki pengaruh paling kuat dalam mempengaruhi loyalitas konsumen.

Pada penelitian selanjutnya diharapkan lebih memberikan gambaran yang lengkap dan menyeluruh jika melibatkan lebih banyak variable dalam penelitiannya, sehingga dapat memberkan gambaran yang lebih komprehensif.

\section{REFERENSI}

Afifah. Dkk. 2017. Pengaruh Aksebilitas, Fasilitas dan Kepuasan Pelanggan Terhadap Loyalitas Pelanggan di Delta Fishing Sidoarjo. Jurnal Manajemen Branchmark. Vol.3 Issue 3, 2017.

Handoko, kuttut dan Suparmi. 2018. Pengaruh Kepuasan, Kepercayaan dan Komitmen Terhadap Loyalitas 
Pelanggan Pada PT. Yodya Karya (Persero) Cabang Utama Semarang. Jurnal Ilmiah UNTAG Semarang. Vol. 7 No.1.

Lupiyoadi, Rambat. 2013. Manajemen Pemasaran Jasa. Salemba Empat, jakarta.

Sari, Lely Kurnia. 2017. Pengaruh Kualitas Layanan, Fasilitas, dan Kepercayaan Terhadap Loyalitas Pelanggan Kereta Api Ekonomi Dhoho.jurnal Ilmu Ekonomi Universitas Nusantara PGRI Kediri. Vol. 01 No.06.

Mudrajad, 2006. Strategi: Bagaimana Meraih Keunggulan Kompetitif?, Erlangga, Jakarta.
Paulus.Dkk. Pengaruh Kualitas Pelayanan dan Harga Terhadapa Loayalitas Pelanggan Pengguna Aplikasi Gojek. Jurnal EMBA Vol.6 No.4 September 2018, Hal. $2778-2787$

Sofiati, Iis. Dkk. 2018. Dampak Kualitas Pelayanan Terhadap Loyalitas Konsumen. Jurnal Sambi Manajemen dan Bisnis Indonesia. Vol.8 No.2.

Siregar, Nurafrina dan Fadillah, Hakim. 2017. Pengaruh Pencitraan, Kualitas Produk dan Harga Terhadap Loyalits Pelanggan Pada Rumah Makan Kampoeng Deli Medan. Jurnal Manajemen tools. Vol.8 No. 2 